\title{
Effect of Islamic Work Ethics on Dimensions of Organizational Justice: A Case of Banks of District Peshawar, KP-Pakistan
}

\author{
MAAZ UD DIN \\ Ph.D. Scholar, Department of Management Sciences \\ University of Swabi, KP-Pakistan \\ maazyousafzai12@gmail.com \\ DR.FAISAL KHAN \\ Assistant Professor, Department of Management Sciences \\ University of Swabi, KP-Pakistan \\ faisalkhanutm@yahoo.com \\ DR. MUHAMMAD FAIZAN MALIK \\ Assistant Professor, Institute of Business Studies and Leadership \\ Abdul Wali Khan University, Mardan \\ Faizanmalik1230@gmail.com
}

\begin{abstract}
The attention of business ethics from Islamic viewpoint has become more significant for business in this modern era. The aim of this study is to examine the consequence of Islamic work ethics on justice perception among the banks of District Peshawar. The concept of organizational justice integrated three measurements, specifically procedural, interactional and distributive justice. Practicing and Potential Personnel were surveyed and adopted questionnaire was used for data collection tools. The sample was collected from 205 employees from different banks operating in District Peshawar. The result proposed that Islamic work ethics significantly contribute the three levels of fairness perceptions. Furthermore, Islamic work ethics influence dimensions of organizational justice positively. Limitations, implications and suggestions for future work are also discussed in this study.
\end{abstract}

Keywords: Islamic work ethics, Procedural justice, Distributive justice, Interactional justice, Banks

\section{Introduction}

In modern years the subsequent failures of chief organizations similar to Arthur Anders, Enron, and World Comstudy interest on work ethic has gain significance attention. Though, in this area more research has been done as in the key subjects of business ethic but majority in the Western states (Rizk, 2008, Lime \& Lay,2003). In western countries research on protestant work ethics has been done by different researches as advocate by Yousef, (2001) and Max Weber. Now with standing he influence PWE of and Protestant is resting on financial growth in the West (Weber, 2002), the applicability of this model base on these parts must be incomplete in nonwestern nations, mainly those who follow to other religions. Islam possesses its own code of conducts as resulting from Hades and Quran. In same way to Weber Protestant is the Islam offers philosophical basis for a multiplicity of individual qualities that endorse financial growth (Ali, 2005). Certainly, agreeing to Ali, the uses 
of IWE took the Muslims to the wonderful era in the eight awaiting14 ${ }^{\text {th }}$ century. Similarly, as Protestant work ethics added to the financial growth of Western society (Weber, 2002), IWEflourish in the growth of Islamic kingdom and captivating the Muslimscivilization to the excellentera in the $14^{\text {th }}$ century. According to Ali (1992), Islamic work ethics lead Muslims behavior and attitude in place of work and gives to the wellbeing of the humanities. Islamic work ethics research interest is extremely incomplete. A small number of research scholar who had been demeanor research on IWE and relate ideas includes Yousaf (2000, 2001),Ali(1998, 1992),(Khan, et al, 2015), Durkhanai et al,(2016) and Khali and Abu Saad(2009). Example Durkhanai (2016) investigate Organization fairness effect on job outcomes: moderating effect of IWE. In this study a sample of 140 employees in public and private universities were considered or the survey. The decided results showpositive effect of procedural justiceand distributive justice on work engagement andorganization citizenship behavior. A significant relation exists between organizational justice and IWE that moderate the predictor (procedural justice, distributive justice) and criterion (organization citizenship behavior and work engagement).

The role of IWE on job outcomes has not gain much concentration in Past particularly in banking sectors of Pakistan. Organization ethics investigators suggested than immoral organizational behavior are established in a diversity of damaging conduct in the organizations (like cheating and lying) (Weaver and Trevino, 2001). The insufficiency of pragmatic researches on IWE and linked make for instance organization fairness is the cause for this research. It was directed to examine the consequence of IWE on three aspects of fairness, specifically, procedural, interactional and distributive justice. The research was demeanor in banks of district Peshawar, Pakistan.

\section{Literature Review}

\subsection{Islamic Work Ethics (IWE)}

IWE was defined by Beekun (1997) as the set of laws that distinguish what is right from what is wrong is Islamic perspective. The ethics is basically originated from Quran, because holy Quran is the only shield for the Muslims in all walks of life. Islamic work ethics stress corporation in work place and consultation is observe avoiding blunders. IWE also stress on innovative effort as a basis of accomplishments and happiness. Durable worker employees are like a virtual and those who effort tough further probable to obtain success in his life. Together Protestant work ethics and IWE and stresses on commitment, work creativity, hard work, devotion to work and avoid of immoral methods of collection of assets gathering, theft, competitiveness and cooperation at place of job(Yousaf,2001).

Several studies have been examined the association of IWE with employees wellbeing and job stress such as Maaz Ud Din and Saad Farooq (2016) and Ajmal and Irfan (2014). These researches provides some reference to the background role played by IWE, However, more studies are required and the role of IWE with conflict, commitment and psychological distress and is still tobe examined for appropriate guidance for the policy makers and practitioners.

Islam visibly oppose Weber's dissertation that Muslims society might not developed their financial system. According to (Arslan, 2000) Weber also claimed Islam might not create standards like Protestant morals "the strength of free enterprise" since of three essentials reasons, first Sufism, it is one the influential factor that is the evasion of globe substance. We presupposed, Sufism is an obstacle to the enlargement of a capitalistism spirits as it inspires a philosophical ways of life. Nextcombatant ethics, 
suggested by Weber is a like to the spirits of take-over. Weber perceives that combatant ethics is an opposite of the innovative capitalistic spirits, as war is intimately linked with obliteration and homicide. Thirdly, oriental tyranny, Weber suggested that the majority of the Islamic states are tyrannical; they limited capital and belongings right buildup. It shaped idleness amongst peoples of organization (Arsalan, 2000). Recently research conducted by $(2000,2001)$ has give pragmatic evidence to reject Weber's dissertation. On protestant work ethics Arsalan (2000) compared Turkish and British managers. He concluded Turkish managers have rate higher scores in all protestant work than British executives. Arsalan thus claimed that Weber's censures of IWE as warning to the behaviors and financial growth is not lawful, particularly in case of Turkish manager samples. Next, spiritual motivations had a vital significant influence on trade or business. According to Arslan (2000), Cavinism and Turkish Sufi movement had the similar function in the North Europe in the $18^{\text {th }}$ centuries and countries was in high position in business ethics and Trade. Ali(1992), also sustained this study, that Arabians executive are extra creative than Western managers.

\subsection{Islamic work ethics and Organizational justice}

To support this research study organizational justice theory delivers a valuable frame work toward sympathetic employees' attitudes towards work, job performance and work behaviors. This is just totally base on employees justices in place of work or organization (Cropanzano, Bowen, and Gilliland, 2007, Colquitt, Conlon, Wesson, Porter, and $\mathrm{Ng}, 2001$ ). The idea of justice has a lengthy past as key descriptive variables in social science(Colquitt, 2001) in organization's framework, fairness means to equality towards organization practices which include pay, selections, promotions, rewards and other means. Fairness in organizationshasbeen of huge concerns to together employees and employers (Folger and Cropanzano, 1998). Many researchers examined that worker insights of organization's justices be an important aspect which influence different job outcomes like job satisfaction, turn over intention, organizational commitment (Cropanzano et al, 2007; Colquitt et al., 2001, Hassan, 2002). Though, research done on organizational justice and ethics has gain slight consideration as of organization behaviors researches. The idea of organizational justice and ethics frequently differentiate themselves among outcomes and process (Schminke, Ambrose \& Noel, 1997).

According to Adam(1965) equity theory high light workers shall regulate their conduct because to make what they believe as evenhandedequilibrium of welfares and burdens at place of work. (Trevino and Weaver, 2001).Emerging the structure of previous researchesconsidered that study on justice change to astress on Procedural equality which wasfoundedon the findings of WalkerandThibaut (1975).They claimed that employees who gainadverse outcomes was fair (Schminke et al., 1997).

There are three dimensions of organizational justice, by according to Colquitt, Greenberg, and Zapata-Phelen(2005)namely:

I) Distributive justices mostly associated to the justice of the results the workers received.

II) Procedural justices, which described the justice use to resolve those consequences.

III) Interactional fairness, which states to excellence of the relationa lcommunication between the individual and firm.

Research on moral code faithfully related to fairness. Ethical studies are focused on individual and how their belief affects the person's insights through organization. 


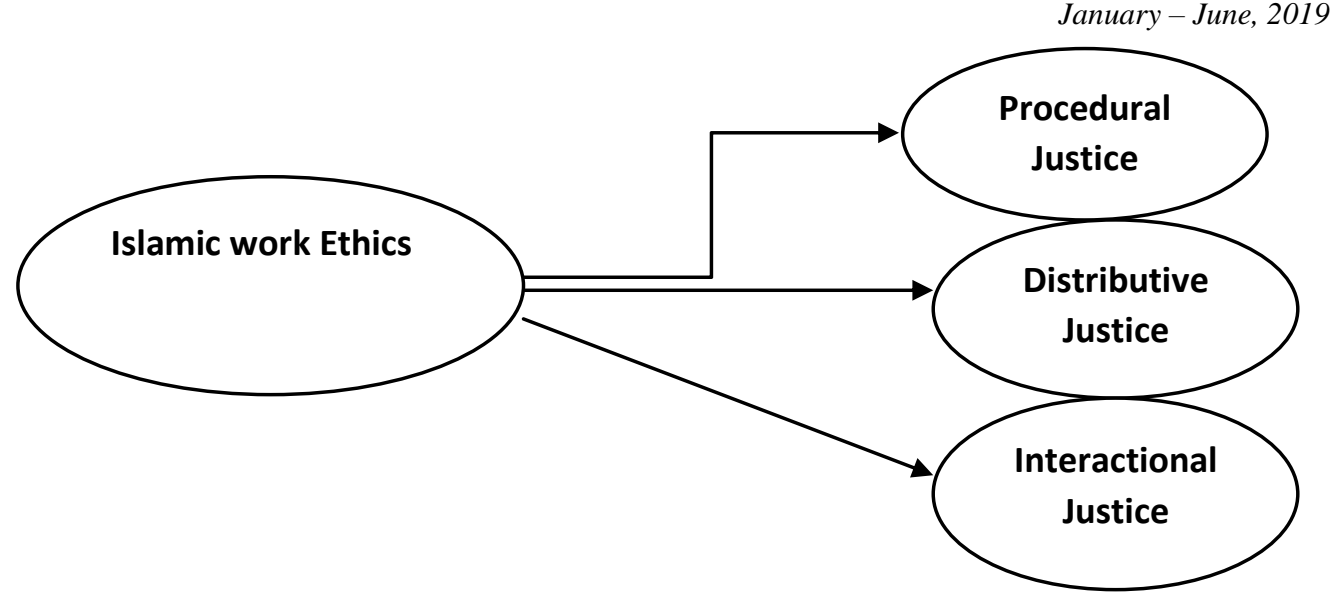

According to Schminke et al., (1997) research on justice is related with the effect of someone view toward organization. Researchers examined that people are eager to, interpreting, presentation and replying to the surroundings in diverse methods giving to their moral outlines, these moral frame work might effects the means the persons outlook more common organization'sproceedings and results too, as well as those connecting the justice of procedural and distributions of job outcomes. The association between effort ethics and fairness had been deliberated in earlier researches. (Like, Schminke et al., 1997 and GreenBerg, 1990). According to Greenberg (1990) the personnel who have more practiced a pay cut should bargain more high than below standard form. Schminke et al., (1997) claimed that moral formalist (Process Base) be more responsive to procedural fairness problems and on the other side; moral useful (outcomes founded) be additional delicate to distributive fairness problems. There were a significant association between apparent general unbiased action and ethics connected results (Trenvino \&Weaver, 2001). In the religion of Islam fairness link with assigning somewhat in its accurate place. In an Islamic context thereare three important phases of justice (Muhammad, 1993). They contains of (i) to place capable person to their appropriate post, in order that he will be beneficial for organization (ii) to make the right decision in any situation for the person who receive it, and (iii) to place property or wealth to those who are the right to deserve it in order the others rights not violated. Beekun and Badawi, (1999) explain fairness is a dynamic quality that every Muslim must struggle to improve may be male or female is a follower or leader. When a Muslim leader have Islamic morals he will demeanoraffair with the qualities of justice in anyfirm. Hence, based on assessment of above literature, the following important hypotheses were constructing. Hypotheses:

H1. IWE will significantly associate to procedural justice.

H2IWE will significantly associate to interactional justice.

H3. IWE will significantly associate to distributive justice.

\section{Research methods}

\subsection{Sample and Population}

This study was demeanor on IWE effect on dimensions of organizational justice in banks of District Peshawar, Pakistan. 40 banks were selected for research as sample from targeted population. Mostly respondents were Pashtuns speak Pashtu language but also understand Urdu so the questionnaires were converted into Urdu. Language expert checked the translation briefly. The samples were drawn from Islamic bank staff of Peshawar. Adopted questionnaire was used for data collection. A total number of 290 full time staffs were demanded to fill the questionnaires of which 205 
questionnaires were reimbursed (Feedback rate was 82\%), 85 filled up questionnaire were useless. Hence, the concluding sample sizes of 205 defendants wereconsidered.

\subsection{Measurements}

Islamic work ethic measurements wereurbanized by Ali (2005) andthis measurement contains of 17 item scales. Instance for these scales includes:idleness is a vice,justice and generosity and dedication to work is a virtueand the working environment are essentialsituation for society wellbeing. In Muslim countries like Saudi Arabia, Malaysia, UAE, Kuwait the short version of the scales has been used in different research related to Islamic work ethics and the results were quite interesting. A five points Likert scales were used range from 1 to 5(Strongly disagree to strongly agree). In this studyto find the reliability of the instrument Cronbach's alpha technique was used and the value of Cronbach's alpha was 0.75.

Organizational justice items scales wereurbanized by Niehoff and Moorman (1993) have 12 item scales. This scale measures mostly justice of the procedures in allocation decisions and the excellence of workers, perceptions of fairness of the resources allocation also interaction with his co-workers and superiors in their organization. The reliability scale for all three magnitudes of organization justice were obtain $0.70,0.85 .0 .90$.

Table I: Demographic of Defendants Demographic Variables Frequency Percentage

\begin{tabular}{|c|c|c|c|}
\hline \multicolumn{4}{|l|}{ Gender } \\
\hline Male & \multicolumn{2}{|l|}{187} & 92 \\
\hline Female & 18 & 8 & \\
\hline Total & 205 & & \\
\hline \multicolumn{4}{|l|}{ Age } \\
\hline $20-30$ & \multirow{2}{*}{\multicolumn{2}{|c|}{60}} & \\
\hline \multicolumn{2}{|l|}{29.27} & & \\
\hline $31-40$ & 70 & & 34.14 \\
\hline $41-50$ & 40 & & 19.51 \\
\hline $51-60$ & 35 & & 17.07 \\
\hline Total & \multicolumn{2}{|c|}{205} & \\
\hline \multicolumn{4}{|l|}{ Experience (years) } \\
\hline $1-5$ & 150 & & 73.17 \\
\hline $6-10$ & 48 & & 23.41 \\
\hline 10 and Above & 7 & 3.41 & \\
\hline Total & 205 & & \\
\hline
\end{tabular}

\subsection{Results:}

Table II, shows Descriptive statistics(Means and SD) and correlations of all variables in the study, i.e., IWE, interactional justice and Procedural justice. The correlation of the variables shows support of suggested hypotheses. Therefore, all three dimensions of organizational justice were shows association and significantly linked with Islamic work ethics.

Table II: Means, Standard Deviation, and Correlations among Variables.

\begin{tabular}{|c|c|c|c|c|}
\hline Variables & Means S.D & 1 & 23 & \\
\hline IWE & 3.62 & 0.48 & 1.00 & \\
\hline Distributive Justice & 3.64 & 0.57 & $.165 * * 1.00$ & \\
\hline Procedural Justice & 3.65 & 0.51 & $.248 * * \quad .459 * *$ & 1.00 \\
\hline
\end{tabular}




\begin{tabular}{llllll}
\hline 4. Interactional Justice & 3.74 & 0.63 & $.136^{* *}$ & $.554^{* *}$ & $.618^{* *}$
\end{tabular}

** Significance at $\mathrm{P}<0.01, \mathrm{P}<0.05$

To deal with the determination of this research the suggested hypotheses were verifiedby consider regression analysis are explain in Table III.As predictable (H1) the regression findings shows that Islamic work ethics is an important predictor of distributive justice as hypothesized $(\mathrm{R} 2=0.219, \mathrm{P}<0.01)$. The find of $(\mathrm{H} 2)$ also supported which shows significant relation between Islamic work ethics and procedural justice. The Islamic work ethics scoresdescribedapproximately $35.6 \%$ of variation $(\mathrm{F}=17.93, \mathrm{P}<0.01)$ in procedural fairness perception. Likewise, $(\mathrm{H} 3)$ was also accepted, signifying that Islamic work ethics contributed to interactional justices too. So, it may be incidental that Islamic work ethics contribute a vital role in forecasting organizational justice dimensions.

Table III: The results of Regression analysis, Islamic work ethics as predictor of organizational justice.

\begin{tabular}{llcc}
\hline & $\mathrm{R} 2$ & F-change & $\mathrm{B}$ \\
\hline Distributive Justice & .219 & $17.93^{* *}$ & $.215^{* *}$ \\
Procedural Justice & .342 & $23.56^{* *}$ & $.242^{* *}$ \\
\begin{tabular}{l} 
Interactional Justice \\
\multicolumn{1}{c}{$192^{* *}$}
\end{tabular} & .192 & $14.54^{* *}$ & \\
\hline$* \mathrm{P}<0.01, * * \mathrm{P}<0.05$ & & &
\end{tabular}

\section{Conclusion, implications and limitations of the study}

The consequence of this study proved that Islamic work ethics has significant association with Procedural justice, interactional justice and distributive justice opinions. Though, IWE inclined to be a sturdy analyst of procedural justices. The results are in line with other researches like led by Schminke et al. (1997), Weaver and Trevino (2001) and Lau and Wong (2009). For instance Trevino and Weaver (2001) examined that there is a significant association the related ethical outcomes and perceived general fair treatment. Moreover, this research as well initiate that a wide range of immoral events were considerably inferior if the personnel supposed that their organizations generally treated them justly. Currently, a research was demeanor by Rokhman and Arif Hassan (2012) used 370 employees from 30 micro finance institutions in central java, Indonesia reported that IWE have influence on organizational justice. Also, an ethical study concern employees and how their attitude influences their perceptions through the organization. According to Schminkie et al., 1997, study on fairness is related with the circumstances which influence the individual opinion towards organization. According to Yousaf(2000) an important principle of the Islamic work ethics is to ensure generosity and justice in place of work, and to opinion the engagement in economic activity as aduty.

The Islamic work ethics regards occupation as a basis of means of endorsing selfesteem and personal growth (Yousaf, 2001). These standards are including in the procedure of decision making, allocating capital and as well value a show of gratefulness or the contributions. Therefore, good feelings of justice in the firm is enriched and established. Also, the Islamic work ethics emphasis on the negligence of dishonest competitiveness and immoral approaches of wealth gathering and deceitful dealing at place of work (Yousaf, 2000). This will afterward have thoughtful effects 
on the justice inside the organization. Therefore, the fundamental code is that the Islamic work ethics have a significant influence on organizational justice. There are some implications of the findings of this study. It deals some exciting rule for managers in religious organization in formulate their HRM strategies and polices particularly the significance of rising morals in the organizations. Further, in order to improve feelings of justices amongst managers, workers needs to sustenance the Islamic work ethics in their organization. Therefore, managers can ensured that each worker joins educational programs as well as different training sessions, which put extra stress on the applications of Islamic ethics and standards in place of work. To conclude, the contributions of this research must be observed in light of various limits. First, the design of this research was not one shot study; it was longitudinal because one shot data are not satisfactory to make implications of cause and effect among the examined variables. Therefore, a longitudinal study design should offer supplementary and strong provision for the effect verified in this study. Second, the generalizability of the results of the current research may be doubtful because of the sample. Third, there is little numeral of variables in this study; it is good for future research to comprise other variables like organization citizenship behavior, job stress, performance and other work related outcomes with IWE to give credible results.

\section{References}

Ali, J.A. (1988). Scaling an Islamic work ethic. Journal of Social Psychology, 128(5): 575-583.

Ali, J.A. (1992). Islamic work ethic in Arabia. Journal of Psychology, 126(5): 507517.

Ali, J.A. (2005). Islamic Perspectives on Management and Organization. Edward Elgar Publishing, UK.

Adam, S. J. (1965). Inequity in social exchange. Inequity in social exchange. In L. Berkowitz (Ed.) Advances in experimental social psychology, 2, 267-299).New York, NY: Academic Press.

Ajmal, M. B., \& Irfan, S. (2014). Understanding the Moderating Role of Islamic Work Ethics

between Job Stress and Work Outcomes. Journal of Business and Management, $16(1)$,

62-67

Arslan, M. (2000). A cross cultural comparison of British and Turkish managers in term of Protestant work ethic characteristics. Business Ethics: A European Review, 9 (1):

Beekun, R. (1997). Islamic Business Ethics. IIIT, Herndon, Virginia, U.S.A.

Beekun, R. and Badawi, J. (1999). Leadership: an Islamic Perspective, Herndon, VA: Amana

Publications.

Colquitt, J. A., Greenberg, J. and Zapata-Phelan, (2005). What is Organizational Justice? A historical overview. In Greenberg and Colquitt (Eds), Handbook of Organizational Justice. LEA Publisher, Mahwah. NJ, 3-56.

Colquitt, J. A., Conlon, D. E., Wesson, M. J., Porter, C. O. L. H. and Ng, K. Y. (2001).Justice at the millennium: A meta-analytic review of 25 years of organizational justice research. Journal of Applied Psychology, 86(3):425-445.

Cropanzano, R., Bowen, D. E. and Gilliland, S. W. (2007). The management of organizational justice. Academy of Management Perspectives, 21: 34-48. 
Durkhanai, A.Saif Ul and K.Samandar, (2016) Organizational justice effect on job outcomes, the moderating role of Islamic work ethics. Entrepreneurship and innovation management service. 4(2):48-62.

Folger, R. and Cropanzano, R. (1998). Organizational Justice and Human Resources Management. Thousand Oaks, London: Sage Publications.

Greenberg, J. (1990). Organizational justice: Yesterday, today and tomorrow. Journal of Management, 16(2):399-342.

Hassan, A. (2002). Organizational justice as a determinant of organizational commitment and intention to leave. Asian Academy of Management Journal, 7(2): 55-66.

Khali and Abu-Saad. (2009). Islamic work ethic among Arab college students in Israel. Cross Cultural Management: An International Journal. 16 (4): 333-346.

Khan, K., Abbas, M., Gul, A., \& Raja, U. (2015). Organizational justice and job outcomes: Moderating role of Islamic work ethic. Journal of Business Ethics, 126(2), 235-246.

Lau, V. and Wong, Y. (2009). Direct and Multiplicative Effects of Ethical Dispositions and Ethical Climates on Personal Justice Norms: A Virtue Ethics Perspective. Journal of Business Ethics, 90 (2):279 - 294.

Lime, C. and Lay, C.S. (2003) Confusiasm and the protestant work ethic". Asia Europe Journal, Vol. 1, 321-322.

Muhammad (1993). Keadilandalam Islam. PustakaPelajar, Yogjakarta.

Maaz. U, \& Farooq, S. (2017). Effect of Islamic Work Ethics on Employee WellBeing, Job

Stress and Turnover Intention. Sarhad Journal of Management Sciences, 2(02), 157163.

Niehoff, B.P. and Moorman, R.H. (1993). Justice as a mediator of the relationship between methods of monitoring and organizational citizenship behavior. Academy of Management Journal, 36: 527-556.

Rizk, R. R. (2008). Back to basics: an Islamic perspective on business and work ethics. Social Responsibility Journal, 1(2): 246-254.

Rokhman, W, Hassan, (2012) A, The effect of Islamic work ethics on organizational justice. African Journal of business ethics.Vol.6.(1)

Schminke, M., Ambrose, M. and Noel, T. (1997). The effect of ethical frameworks on perceptions of organizational justice. Academy of Management Journal, 40(5): 1190 1207.

Weber, M. (2002), The Protestant Ethic and the "Spirit" of Capitalism, Penguin Classics, New York, NY.

Weaver, G and Trevino, L. (2001). Organizational Justice and ethic program "followtrough": influences on employees' harmful and helpful behavior. Business Ethics Quarterly, 11(4): 651-657.

Walker, L and Thibaut, J. (1975). Procedural Justice: A Psychological Analysis. Hillsdale, NJ: Lawrence Erlbaum Associates.

Yousef, D. A. (2000). Organizational commitment as a mediator of the relationship between Islamic work ethic and attitudes toward organizational change. Human Relations, 53 (4): 513-37.

Yousef, D. A. (2001). Islamic work ethic - A moderator between organizational commitment and job satisfaction in a cross-cultural context. Personnel Review, 30 